\title{
Evolution of Tumor Clones in Adult Acute Lymphoblastic Leukemia
}

\author{
S. Yu. Smirnova', Yu. V. Sidorova', N. V. Ryzhikova', K. A. Sychevskaya², E. N. Parovichnikova', \\ A. B. Sudarikov ${ }^{1 *}$ \\ ${ }^{1}$ National Hematology Research Center, Novy Zykovskiy Proezd, 4a, Moscow, 125167, Russia \\ ${ }^{2}$ Faculty of Basic Medicine, Lomonosov Moscow State University, Lomonosov Ave., 31 /5, \\ Moscow, 119192, Russia \\ "E-mail: dusha@blood.ru \\ Received February 10, 2016; in final form April 01, 2016 \\ Copyright $\odot 2016$ Park-media, Ltd. This is an open access article distributed under the Creative Commons Attribution License, which permits \\ unrestricted use, distribution, and reproduction in any medium, provided the original work is properly cited.
}

\begin{abstract}
Clonal instability of a tumor cell population in acute lymphoblastic leukemia (ALL) may complicate the monitoring of a minimal residual disease (MRD) by means of patient-specific targets identified at the disease onset. Most of the data concerning the possible instability of rearranged clonal TCR and IG genes during disease recurrence were obtained for ALL in children. The appropriate features of adult ALL, which are known to differ from those of childhood ALL in certain biological characteristics and prognosis, remain insufficiently studied. The aim of this study was to assess the stability of $I G$ and $T C R$ gene rearrangements in adult ALL. Rearrangements were identified according to the BIOMED-2 protocol (PCR followed by fragment analysis). Mismatch in clonal rearrangements at onset and relapse was identified in $83 \%$ of patients, indicating clonal instability during treatment. Clonal evolution and diversity of $I G$ and $T C R$ gene rearrangements may be one of the tumor progression mechanisms. New rearrangements may emerge due to residual VDJ-recombinase activity in tumor cells. Also, many clonal $I G$ and $T C R$ gene rearrangements may be present at different levels at a diagnosis, but less abundant clones may be "invisible" due to limited detection sensitivity. Later, major clones may disappear in the course of chemotherapy, while others may proliferate. Investigation of clonal evolution and heterogeneity in ALL and their impact on the treatment efficacy will contribute to the identification of new prognostic factors and the development of therapeutic approaches.
\end{abstract}

KEYWORDS acute lymphoblastic leukemia, relapse, PCR, IG and TCR gene rearrangements.

ABBREVIATIONS ALL - acute lymphoblastic leukemia; MRD - minimal residual disease; RT-PCR - real-time PCR; TCR - T cell receptor; TCRG - T cell receptor $\gamma$; TCRB - T cell receptor $\beta$; TCRD - T cell receptor $\delta$; IG immunoglobulin; IGH - immunoglobulin heavy chain; IGK - light chain $x$.

\section{INTRODUCTION}

Acute leukemias are a heterogeneous group of neoplastic diseases of the hematopoietic tissue, which are characterized by overproduction and accumulation of morphologically immature (blast) hematopoietic cells in the bone marrow. Depending on the hematopoietic lineage giving rise to tumor cells, acute leukemias are conventionally divided into acute lymphoblastic and acute myeloid leukemias. Untreated, the disease rapidly progresses and always results in the death of the patient. The most common causes of death are severe infectious and hemorrhagic complications arising from the replacement of normal hematopoietic tissue with blast cells.

The central goal of a treatment for any type of leukemia is the eradication of the tumor clone, restoration of normal hematopoiesis, and the achievement of longterm relapse-free survival of patients. The introduction of cytostatic drugs in clinical practice in the late 1960s enabled the achievement of complete remission in $85-95 \%$ of children with ALL [1]. In that case, an important prognostic factor is age; event-free survival of children in various age groups varies from $83-97 \%$ (1-5 years) to $49-66 \%$ (10-15 years). Recently, the Russian Research Group for the Treatment of Acute Lymphoblastic Leukemia (RALL) has demonstrated that the 5 -year relapse-free survival rate in adult patients under 30 years of age is $71.5 \%$, while this indicator in patients aged $30-55$ years is lower $-61.8 \%$ [2]. Adults and children with ALL have been demonstrated to differ not only in the survival rate, but also in the biological properties and prognosis of the disease [3, 4]. In particular, a favorable prognostic group in adults includes the $\mathrm{T}$ cell type of the disease, whereas this type in children is considered prognostically adverse. In addition, adults are more likely to show prognostically adverse chromosomal aberrations $(\mathrm{t}(9 ; 22), \mathrm{t}(4 ; 11))$, myeloid antigens on the membrane of tumor cells, and hyperleu- 
kocytosis at the disease onset, and they are more often diagnosed with the T-cell immunophenotype [3, 4].

Another important factor that affects the prognosis in ALL is the residual amount of tumor cells in the bone marrow, or minimal residual disease (MRD). MRD evaluation is considered not only as an independent prognostic factor, but also as a criterion for allocating patients into relapse risk groups [5-7]. The most suitable for MRD quantification are techniques with the highest sensitivity level $\left(10^{-4}-10^{-5}\right)$, such as real-time PCR (RT-PCR) with patient-specific primers, as well as multicolor flow cytometry. MRD evaluation in ALL patients by PCR is based on the identification of the clonal rearrangements of the T-cell receptor (TCR) and the immunoglobulin (IG) genes in the tumor cells, and the selection of patient-specific primers to the CDR3region of the genes [8].

Clonal rearrangements of the IG and TCR genes occur in $98 \%$ of B-ALL patients and in $95 \%$ of T-ALL patients [9]. Because different chromosomal aberrations are found in tumor cells derived from different patients, only rearranged IG and TCR genes are considered to be universal markers for monitoring tumor clones in almost all patients during disease/therapy. Detection of clonality alone is not enough for ALL diagnosis. Clonal rearrangements are sometimes found also in the reactive (non-tumor) processes of inflammatory, infectious, or autoimmune genesis. A clonal product in these cases is usually detected on a polyclonal background. The differential diagnosis between tumor and non-tumor lymphoproliferation is somewhat difficult in some lymphomas, mycosis fungoides, and Sezary syndrome; however, a study of clonality in ALL when most peripheral blood lymphocytes $(>20 \%)$ are represented by tumor cells is not associated with these difficulties.

RT-PCR with patient-specific primers selected for a unique nucleotide sequence of the $\mathrm{V}$-D-J-region of clonally rearranged $I G$ or TCR genes enables a highly sensitive $\left(10^{-4}-10^{-5}\right)$ evaluation of the amount of residual tumor cells in ALL patients [10]. However, the data obtained from studying clonal rearrangements at the onset and relapse of ALL in children indicate that $I G$ and TCR gene rearrangements can change during the disease: part of the identified clonal rearrangements disappears at relapse, and/or new rearrangements emerge. It should be noted that we are talking just about a partial change in clonal rearrangements, because a complete change in $I G$ and TCR gene rearrangements at relapse indicates a development of secondary ALL $[11,12]$. Partial differences in clonal rearrangements at the onset and relapse occur in $67-70 \%$ of children with B-ALL and in $45-50 \%$ of children with T-ALL [13-15]. Data on the evolution of tumor clones in adult ALL is scant [11]. Szczepanski et al. reported on an evaluation of TCR genes in 9 adults with T-ALL [11]. The overall stability of TCR genes in the adult T-ALL was shown to be higher (97\%) than that in childhood T-ALL (86\%) [11]. However, IG gene rearrangements at the onset and relapse were not studied.

Alteration of clonal rearrangements, i.e. clonal evolution of the tumor, may lead to a loss of the target for MRD studies and to false negative results. Therefore, the suitability of a particular rearrangement to study MDR in ALL is determined not only by the rearrangement detection frequency, but also by its stability. The crucial data on the stability and frequency of various rearrangements in B-ALL and T-ALL are summarized in Table 1 [5-11, 15-19].

TCR $\delta$-chain (TCRD) gene rearrangements are specific to early stages of $\mathrm{T}$ cells development and occur in about $55 \%$ of T-ALL cases only [20]. TCR $\gamma$-chain (TCRG) gene rearrangements occur in $95 \%$ of T-ALL patients [21]; TCR $\beta$-chain (TCRB) gene rearrangements occur in $92 \%$ of T-ALL patients. The stability of TCRB rearrangements in T-ALL relapses in children was shown to be lower than that of $\gamma$ - and $\delta$-chains 80, 86, and 100\%, respectively (Table 1) [11]. Despite a high detection rate and high stability, monoclonal rearrangements of $\gamma$-chain genes are not the best target for MRD monitoring, because they possess a short fragment of inserted nucleotides [22]. According to the published data, T-ALL is often more resistant to therapy and, therefore, MRD positive than B-ALL [23]. A high stability of IGK gene rearrangements $(95 \%)$ in BALL children, complete V-D-J-rearrangements of the IGH (88\%), TCRB (89\%), and TCRD (86\%) genes, a relatively high stability of TCRG gene rearrangements $(75 \%)$, and a low stability of incomplete (D-J) rearrangements of $I G H$ genes $(57 \%)$ and incomplete rearrangements of TCRB genes (67\%) were established (Table 1). Furthermore, oligoclonal rearrangements were initially detected in a large proportion of childhood B-ALL cases $(26-30 \%)$ [13-15]. Clonal products of an incomplete gene rearrangement and derived clonal products with complete rearrangements can be present in ALL, which is explained by the action of $\mathrm{V}(\mathrm{D}) \mathrm{J}$-recombinases and the ongoing process of immunoglobulin and TCR gene rearrangements in early progenitor cells [11, 15, 24]. Oligoclonality (presence of two or more clones) is most often detected in IGH genes: complete rearrangements - in $30-40 \%$ of cases, incomplete rearrangements - in $50-60 \%$ of cases, and TCR $\delta$-chain gene rearrangements - in 20-25\% of cases (Table 1). Oligoclonal rearrangements are not recommended for use as a target for MRD evaluation, because they are unstable and often produce false negative results. 
Table 1. Stability and detection the rate of clonal rearrangements in B-ALL and T-ALL [7]

\begin{tabular}{|c|c|c|c|c|c|c|c|}
\hline \multirow{3}{*}{ Gene } & \multirow{3}{*}{ Rearrangement } & \multicolumn{4}{|c|}{ B-ALL } & \multicolumn{2}{|c|}{ T-ALL } \\
\hline & & \multicolumn{2}{|c|}{ Rate, $\%$} & \multicolumn{2}{|c|}{ Stability, \% } & \multirow{2}{*}{ Rate, \% } & \multirow{2}{*}{ Stability, $\%$} \\
\hline & & mono & oligo & mono & oligo & & \\
\hline \multirow[t]{3}{*}{ IGH } & VH-JH (complete) & 93 & $30-40$ & 88 & 47 & 5 & NT \\
\hline & DH-JH (incomplete) & 20 & $50-60$ & 57 & 38 & 23 & NT \\
\hline & All IGH & 98 & 40 & 85 & 44 & 23 & NT \\
\hline \multirow[t]{3}{*}{ IGK } & $\mathrm{V} x$-Kde & 45 & $5-10$ & 95 & 40 & 0 & $\mathrm{NA}$ \\
\hline & Intron RSS-Kde & 25 & $5-10$ & 86 & 0 & 0 & NA \\
\hline & All Kde & 50 & $5-10$ & 95 & 40 & 0 & NA \\
\hline \multirow[t]{3}{*}{ TCRB } & VB-JB (complete) & 21 & $10-15$ & 89 & 60 & 77 & 79 \\
\hline & DB-JB (incomplete) & 14 & $10-15$ & 67 & 0 & 55 & 80 \\
\hline & All TCRB & 33 & $10-15$ & 81 & 43 & 92 & 80 \\
\hline TCRG & VG-JG & 55 & 15 & \multicolumn{2}{|c|}{75} & 95 & 86 \\
\hline \multirow[t]{3}{*}{ TCRD } & VD-JD or DD-JD1 & $<1$ & $\mathrm{NA}$ & NA & NA & 50 & 100 \\
\hline & VD2-DD3 or DD2-DD3 & 40 & $20-25$ & 86 & 26 & 55 & 100 \\
\hline & All TCRD & $40 \%$ & $20-25 \%$ & $86 \%$ & $26 \%$ & $55 \%$ & $100 \%$ \\
\hline
\end{tabular}

Note. NT - not tested, NA - not applicable.

The evolution of tumor cells (alteration of clonal TCR and IGH gene rearrangements) at relapse has been studied mainly in childhood ALL. Data on adult ALL is very limited. Given that adult and childhood ALLs have different biological characteristics and prognosis, the aim of our study was to examine patterns of clonal immunoglobulin and T-cell receptor gene rearrangements and how stable they are in adults with B-ALL and T-ALL who had undergone treatment at the Hematology Research Center.

\section{MATERIALS AND METHODS}

Patients and samples

The study included 63 ALL patients: 34 patients with B-cell ALL, including two patients with Ph+ ALL; 28 patients with T-cell ALL; and one patient with biphenotypic ALL (Table 2). All patients underwent a standard cytogenetic examination and a FISH-study of bone marrow cells using fluorescent probes $\mathrm{t}(9 ; 22)$ and $\mathrm{t}(4 ; 11)$ (Table 3$)$. Out of the 63 patients, 20 had a normal karyotype, 17 had no mitosis, and six had different variations of chromosome 9 and/or 22. The translocation $\mathrm{t}(9 ; 22)$ was detected by FISH, and the chimeric transcript BCR/ABL (p190) was identified by a molecular-genetic method ( $\mathrm{Ph}+\mathrm{B}-\mathrm{ALL})$. In five patients, the translocation $t(4 ; 11)$ was identified by FISH and the chimeric transcript MLL-EPS15 was detected by PCR. Multiple chromosomal abnormalities were found in seven patients; four patients had trisomy 21 . We studied DNA from all 63 samples of bone marrow at the disease onset. The patients' age ranged from 19 to 59 years
Table 2. Brief characteristics of ALL patients

\begin{tabular}{|c|c|}
\hline Age, years & $19-59(\mathrm{M}, 28)$ \\
\hline Gender, M/F & $32 / 31$ \\
\hline B-ALL/T-ALL/biphenotypic ALL & $34 / 28 / 1$ \\
\hline Number of relapses (B-ALL/T-ALL) & $6(4 / 2)$ \\
\hline Relapse-free time, months & $5.4-11.6(\mathrm{M}, 6.2)$ \\
\hline
\end{tabular}

Note. $M-$ median age.

(median, 28 years). In 6 of the 63 patients, clonal rearrangements were studied at the onset and relapse. The time to relapse ranged from 5.4 to 11.6 months. The patients were observed at the Department of Chemotherapy for Hemoblastoses and Hematopoiesis Depressions of the Hematology Research Center (HRC). The diagnosis was made according to the WHO classification. All the patients enrolled in the study provided their consent to data processing. Blood from healthy donors was obtained at the HRC blood transfusion department.

\section{Analysis of clonality using $I G / T C R$}

gene rearrangements

Leukocytes and DNA were isolated from peripheral blood as described previously [25]. The DNA concentration was determined spectrophotometrically. DNA samples were stored at $-20{ }^{\circ} \mathrm{C}$. B- and T-cell clonality was determined using multiplex BIOMED-2 prim- 
Table 3. Results of conventional cytogenetic testing and FISH-analysis of translocations $t(4 ; 11)$ and $t(9 ; 22)$ in $\mathrm{ALL}$ patients

\begin{tabular}{|c|c|c|}
\hline Patient & ALL type & conventional cytogenetic testing, FISH, PCR \\
\hline 1 & B-II & No mitosis \\
\hline 2 & B-I & Normal karyotype \\
\hline 3 & B-I & $\operatorname{der}(7) \operatorname{add}(\mathrm{p} 22),-8 ?, \operatorname{der}(9), \mathrm{i}(\mathrm{q} 10), \operatorname{der}(14), \operatorname{add}(\mathrm{q} 32 ?),+\operatorname{mar} \operatorname{der}(9) ?(17) \mathrm{cp} / 46, \mathrm{XX}[3]$ \\
\hline 4 & B-I & $\begin{array}{c}\text { Additional material on the short arm of chromosome } 10 \text {; trisomy of chromosomes X, } 12 \text {, and } 22 ; \text { FISH t( } 4 ; 11) \text {; } \\
\text { MLL-EPS15 identified by PCR }\end{array}$ \\
\hline 5 & B-I & $\begin{array}{c}\text { 55XX; derivatives of chromosomes } 3 \text { and } 11 \text {; deletion of the short arm of chromosome } 12 \text { and the long arm of } \\
\text { chromosome } 13\end{array}$ \\
\hline 6 & B-I & Normal karyotype \\
\hline 7 & B-I & Normal karyotype \\
\hline 8 & B-I & No mitosis, FISH t(4;11), MLL-EPS15 identified by PCR \\
\hline 9 & B-II & $\begin{array}{c}\text { Additional signal from an IGH gene locus (14q32) was identified in } 80 \% \text { of nuclei (trisomy of chromosome } 14 ? \\
\text { another translocation involving an IGH gene locus) }\end{array}$ \\
\hline 10 & B-II & Normal karyotype \\
\hline 11 & B-II & No mitosis \\
\hline 12 & B-II & $53 \mathrm{XY} ?+\mathrm{X},+4,+6,+14,+21,+21,+\operatorname{mar}[10]$ \\
\hline 13 & B-II & Normal karyotype \\
\hline 14 & B-II & No mitosis \\
\hline 15 & B-II & No mitosis \\
\hline 16 & B-II & $\begin{array}{l}\text { In } 15 \%, \text { two additional signals each from loci of } \mathrm{ABL}(9 \mathrm{q} 34) \text { and BCR (22q11) genes, tetrasomy of chromosomes } 9 \\
\text { and } 22 ?\end{array}$ \\
\hline 17 & B-II & Trisomy 21 \\
\hline 18 & B-II & Normal karyotype \\
\hline 19 & B-II & Trisomy 21 \\
\hline 20 & B-II & Trisomy 21 , monosomy 13 \\
\hline 21 & B-II & Normal karyotype \\
\hline 22 & B-II & No mitosis \\
\hline 23 & B-II & Normal karyotype \\
\hline 24 & B-II & Normal karyotype \\
\hline 25 & B-II & Normal karyotype \\
\hline 26 & B-III & Two cells with del (11), FISH t(4;11), MLL-EPS15 identified by PCR \\
\hline 27 & B-III & Normal karyotype \\
\hline 28 & B-III & $47 X X+5(5 q 31)$ \\
\hline 29 & B-III & $54 \mathrm{X}, ?+\mathrm{X}, \mathrm{Y},+4,+5,+6, ?-7,+14,+21,+22,+? \operatorname{mar}$ or $\mathrm{i}(7)(\mathrm{q} 10)$ or $\mathrm{i}(8)(\mathrm{q} 10),+\operatorname{mar}[19], 46 \mathrm{XY}$ \\
\hline 30 & B-III & $+8+11+21$ \\
\hline 31 & $\mathrm{~B}-\mathrm{Ph}+$ & No mitosis, FISH t $(9 ; 22), B C R-A B L$ identified by PCR \\
\hline 32 & $\mathrm{~B}-\mathrm{Ph}+$ & Normal karyotype, FISH t $(9 ; 22), B C R-A B L$ identified by PCR \\
\hline 33 & B-II & No mitosis \\
\hline 34 & B-II & No mitosis \\
\hline 35 & T-I & $46 \mathrm{XY}[2] / 90-92, \mathrm{XXYY},=\operatorname{mar}[10]$ \\
\hline 36 & T-I & No mitosis \\
\hline 37 & T-I & $11 q 23$ rearranged, FISH t(4;11), MLL-EPS15 identified by PCR \\
\hline 38 & T-I & Normal karyotype \\
\hline 39 & T-I & $\operatorname{del} 9(\mathrm{p} 13)$ \\
\hline 40 & T-I & No mitosis \\
\hline 41 & T-I & Normal karyotype \\
\hline 42 & T-I & Trisomy in $15.5 \%$; in $45 \%$ tetrasomy in the gene locus PMLL $\backslash 11 \mathrm{q} 23$; FISH $\mathrm{t}(4 ; 11)$; MLL-EPS15 identified by PCR \\
\hline 43 & T-I & Normal karyotype \\
\hline 44 & T-II & Normal karyotype \\
\hline 45 & T-II & Normal karyotype \\
\hline 46 & T-II & Normal karyotype \\
\hline 47 & T-II & No mitosis \\
\hline 48 & T-II & $\begin{array}{l}\text { Deletion of the long arm of chromosome } 5 \text { ? or translocation } t(5 ; \text {;), derivatives of chromosomes } 2,4,5,7,22 \text {, and } 17 \\
\text { (with involvement of the p53 gene) }\end{array}$ \\
\hline 49 & T-II & Trisomy of chromosome 8 \\
\hline 50 & T-II & $(47, \mathrm{XY},+8(20))$ \\
\hline 51 & T-II & Normal karyotype \\
\hline 52 & T-II & No mitosis \\
\hline 53 & T-III & Normal karyotype \\
\hline 54 & T-III & $47, \mathrm{XY}+\operatorname{mar}[20]$ \\
\hline 55 & T-III & der(1)add(p36)?dup(p31p36)?\{20\}; momosomy 9 or deletion of locus 9q34 \\
\hline 56 & T-III & 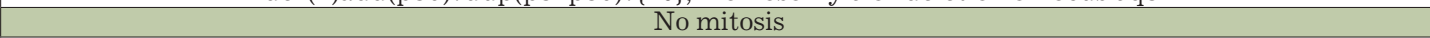 \\
\hline 57 & T-III & Derivative of chromosome 11, deletion of the long arm of chromosome 6 \\
\hline 58 & T-III & No mitosis \\
\hline 59 & T-III & No mitosis \\
\hline 60 & T-III & No mitosis \\
\hline 61 & T-IV & $t(6 ; 17)+20$ \\
\hline 62 & $\mathrm{~T}-\mathrm{I}$ & del 11q23 \\
\hline 63 & $\begin{array}{l}\text { Biphenotypic } \\
\text { ALL }\end{array}$ & 47, XY, der(2)add(p24-25), +5, del(7)(q22), del(13)(q11-q34), +14[6]/46, XY[4] \\
\hline
\end{tabular}

Note: relapsed patients with identified rearrangements of T-cell receptor genes and immunoglobulin genes at the onset and relapse are shown in bold. 
Table 4. Description of multiplex reactions and PCR primers according to the BIOMED-2 protocol

\begin{tabular}{|c|c|c|c|c|}
\hline Gene & Primer set & Forward primers & Reverse primers (labeled) & Product length, bp \\
\hline \multirow{5}{*}{ IGH } & $\mathrm{A}$ & VH1-7 (FR1) & JHcons FAM & $310-360$ \\
\hline & $\mathrm{B}$ & VH1-7 (FR2) & JHcons FAM & $250-295$ \\
\hline & $\mathrm{C}$ & VH1-7 (FR3) & JHcons FAM & $100-170$ \\
\hline & $\mathrm{E}$ & DH1-6 & JHcons TAMRA & $110-290$ and $390-420$ \\
\hline & $\mathrm{D}$ & DH7 & JHcons TAMRA & $100-130$ \\
\hline \multirow{2}{*}{ IGK } & A & $\mathrm{V} x 1 / 6-7$ & Jx1-4, Jx5 FAM & $120-300$ \\
\hline & $\mathrm{B}$ & Vx1/6-7, INTR & KDE-FAM & $210-390$ \\
\hline \multirow[t]{2}{*}{ TCRD } & D1 & D $\delta 2, \mathrm{~V} \delta 1-\mathrm{V} \delta 6$ & 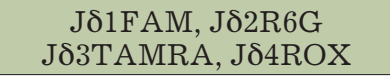 & $120-280$ \\
\hline & D2 & $\mathrm{D} \delta 2, \mathrm{~V} \delta 1-\mathrm{V} \delta 6$ & 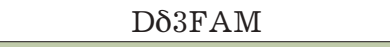 & $130-280$ \\
\hline \multirow{2}{*}{ TCRG } & GA & $\mathrm{V} \gamma 1 \mathrm{f}, \mathrm{V} \gamma 10$ & J $\gamma 1 / 2 \mathrm{FAM}, \mathrm{Jp} 1 / 2 \mathrm{R} 6 \mathrm{G}$ & $145-255$ \\
\hline & GB & $\mathrm{V} \gamma 9, \mathrm{~V} \gamma 11$ & J $\gamma 1 / 2 \mathrm{FAM}, \mathrm{Jp} 1 / 2 \mathrm{R} 6 \mathrm{G}$ & $80-220$ \\
\hline \multirow{3}{*}{ TCRB } & A & 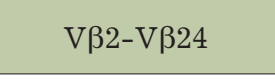 & $\begin{array}{c}\mathrm{J} \beta 1.1, \mathrm{~J} \beta 1.6 \mathrm{HEX} \\
\mathrm{J} \beta 2.2, \mathrm{~J} \beta 2.6, \mathrm{~J} \beta 2.7 \mathrm{FAM}\end{array}$ & $240-285$ \\
\hline & $\mathrm{B}$ & 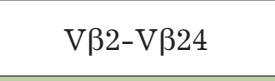 & $\begin{array}{c}\mathrm{J} \beta 2.1, \mathrm{~J} \beta 2.3, \mathrm{~J} \beta 2.4, \\
\mathrm{~J} \beta 2.5 \text { FAM }\end{array}$ & $240-285$ \\
\hline & $\mathrm{C}$ & $\mathrm{D} \beta 1, \mathrm{D} \beta 2$ & $\begin{array}{l}\text { J } \beta 1.1, \text { J } \beta 1.6 \mathrm{HEX} \\
\mathrm{J} \beta 2.1, \mathrm{~J} \beta 2.7 \mathrm{FAM}\end{array}$ & $\begin{array}{l}170-210 \\
285-325\end{array}$ \\
\hline
\end{tabular}

er sets for fragment analysis [26]. B-cell clonality was evaluated by IGH heavy chain (VH-JH FR1/FR2/ FR3/DH-JH) and IGK $x$-light chain (Vk-Jk/Vk-KDE/ IntronRSS-KDE) gene rearrangements. T-cell clonality was evaluated by gene rearrangements of the $\mathrm{T}$-cell receptors TCRG (VG-JG), TCRB (VB-JB/DB-JB), and TCRD (VD-JD/DD2-JD/VD-DD3/DD2-DD3). All IG and TCR gene loci were analyzed in multiplex reactions with a large number of primers clustered in several tubes according to the BIOMED-2 protocol recommendations (briefly described in Table 4). The TCRB genes were amplified using a TCRB Gene Clonality Assay ABI Fluorescence Detection kit (Invivoscribe Technologies, USA) according to the manufacturer's recommendations. A mixture $(25 \mu \mathrm{L})$ for the PCR of the IGH, IGK, TCRG, and TCRD genes contained $5 \mathrm{pM}$ of each primer (Synthol, Russia), 100-200 ng of DNA, and $12.5 \mu \mathrm{L}$ of $2 \times$ PCRMasterMix (Promega, USA). Amplification was performed on a DNAEngine automated thermocycler (BioRad, USA). PCR conditions were as follows: $95{ }^{\circ} \mathrm{C}(7 \mathrm{~min})$, then 35 cycles of $95^{\circ} \mathrm{C}(45 \mathrm{~s}), 60{ }^{\circ} \mathrm{C}$ $(45 \mathrm{~s}), 72{ }^{\circ} \mathrm{C}(45 \mathrm{~s})$, and $72{ }^{\circ} \mathrm{C}(10 \mathrm{~min})$. The cell lines Jurkat and Daudi were used as a positive (clonal) control. Peripheral blood mononuclear cells of healthy donors were used as a polyclonal control. A fragment analysis of PCR products was performed on an ABIPRISM 3130 Genetic Analyzer (Applied Biosystems, USA). For this purpose, $2 \mu \mathrm{L}$ of a 20 -fold diluted PCR product was mixed with $10 \mu \mathrm{L}$ of Hi-Di formamide (Applied Biosystems, USA) and $0.04 \mu \mathrm{L}$ of a GeneScan 500-LIS Size Standard (Applied Biosystems, USA). After de- naturation at $95{ }^{\circ} \mathrm{C}$ for $3 \mathrm{~min}$ and subsequent cooling, $10 \mu \mathrm{L}$ of the mixture was added to a well of a 96 -well plate and high resolution capillary electrophoresis was performed on a POP-4 polymer (Applied Biosystems, USA). The fluorescence of amplicons and their profile were evaluated using the GeneMapper v.4.0 software (Applied Biosystems, USA).

\section{RESULTS AND DISCUSSION}

Clonal rearrangements were studied in 34 patients with B-cell ALL, 28 patients with T-cell ALL, and 1 patient with biphenotypic ALL. The frequencies of clonal TCR $\gamma-, \beta-$, and $\delta$-chain and IG heavy- and light-chain gene rearrangements in B- and T-ALL are presented in $\mathrm{Ta}$ ble 5. A biallelic rearrangement (two peaks) of TCRG genes and an oligoclonal rearrangement (four peaks) of TCRD genes were detected in the patient with biphenotypic ALL. In patients with B-cell ALL, the IG heavy-chain $(82.4 \%)$ and TCR $\gamma$-chain $(76.5 \%)$ gene rearrangements were the most frequent; TCR $\beta$-chain and IG $x$-chain gene rearrangements were found in $38.2 \%$ of cases; TCR $\delta$-chain gene rearrangements occurred in $55.9 \%$ of cases. In patients with T-cell ALL, TCR $\gamma$-, $\delta$-, and $\beta$-chain gene rearrangements were detected in $89.3 \%, 64.3 \%$, and $60.7 \%$ of cases, respectively. IGH rearrangements in T-ALL occurred less often $(28.6 \%)$ than others. A Vk/KDE rearrangement of immunoglobulin $x$-light chain genes was found in one case of T-ALL. Our data on the frequency of clonal IG and TCR gene rearrangements somewhat differ from the data obtained in international studies, which may 
Table 5. Detection rate (\%) of clonal TCR $\gamma-, \beta-$, and $\delta$-chain gene rearrangements and IG heavy- and light-chain gene rearrangements in B- and T-ALL

\begin{tabular}{|c|c|c|c|}
\hline \multicolumn{2}{|c|}{ Rearrangements } & B-ALL $(n=34)$ & T-ALL $(n=28)$ \\
\hline \multirow{3}{*}{ TCRG } & VG-JG & $74.3(n=26)$ & $89.3(n=25)$ \\
\hline \multirow{3}{*}{ TCRB } & VB-JB (complete) & $26.5(n=9)$ & $50(n=14)$ \\
\cline { 2 - 4 } & DB-JB (incomplete) & $23.5(n=8)$ & $46.4(n=13)$ \\
\cline { 2 - 4 } & All TCRB & $38.2(n=13)$ & $60.7(n=17)$ \\
\hline \multirow{3}{*}{ TCRD } & VD-JD/DD2-JD & $17.6(n=6)$ & $53.6(n=15)$ \\
\cline { 2 - 4 } & VD-DD3/DD2-DD3 & $47.1(n=16)$ & $32.1(n=9)$ \\
\cline { 2 - 4 } & All TCRD & $55.9(n=19)$ & $74.3(n=18)$ \\
\hline \multirow{3}{*}{ IGH } & VH-JHFR1/FR2/FR3 (complete) & $73.5(n=25)$ & $25(n=2)$ \\
\cline { 2 - 4 } & DH-JH (incomplete) & $26.5(n=9)$ & $28.6(n=8)$ \\
\cline { 2 - 4 } & All IGH & $82.4(n=28)$ & $0(n=0)$ \\
\hline \multirow{3}{*}{ IGK } & Vk-Jk & $26.5(n=9)$ & $3.6(n=1)$ \\
\cline { 2 - 4 } & Vk-KDE/Intron RSS-KDE & $26.5(n=9)$ & $3.6(n=1)$ \\
\cline { 2 - 4 } & All IGK & $38.2(n=13)$ & \\
\hline
\end{tabular}

Table 6. Clonal products identified at the onset and relapse in six patients diagnosed with ALL

\begin{tabular}{|c|c|c|c|c|c|c|c|c|c|c|c|c|}
\hline \multirow{2}{*}{$\begin{array}{l}\text { Patient/ } \\
\text { diagnosis }\end{array}$} & \multicolumn{2}{|c|}{$\begin{array}{l}\text { Case } 1 \\
\text { T-ALL }\end{array}$} & \multicolumn{2}{|c|}{$\begin{array}{l}\text { Case } 2 \\
\text { T-ALL }\end{array}$} & \multicolumn{2}{|c|}{$\begin{array}{l}\text { Case } 3 \\
\text { B-ALL }\end{array}$} & \multicolumn{2}{|c|}{$\begin{array}{l}\text { Case } 4 \\
\text { B-ALL }\end{array}$} & \multicolumn{2}{|c|}{$\begin{array}{l}\text { Case } 5 \\
\text { B-ALL }\end{array}$} & \multicolumn{2}{|c|}{$\begin{array}{l}\text { Case } 6 \\
\text { B-ALL }\end{array}$} \\
\hline & $\mathrm{O}$ & $\mathrm{R}$ & $\mathrm{O}$ & $\mathrm{R}$ & $\mathrm{O}$ & $\mathrm{R}$ & $\mathrm{O}$ & $\mathrm{R}$ & $\mathrm{O}$ & $\mathrm{R}$ & $\mathrm{O}$ & $\mathrm{R}$ \\
\hline TCRG-GA & + & + & + & + & - & - & + & - & - & + & + & + \\
\hline TCRG-GB & + & + & - & - & - & - & + & - & - & + & - & + \\
\hline TCRB-A & + & + & - & - & - & - & + & - & - & - & - & + \\
\hline TCRB-B & - & - & - & - & - & - & - & - & - & - & + & + \\
\hline TCRB-C & - & - & - & - & - & - & - & - & - & - & - & - \\
\hline TCRD-D1 & + & + & + & +1 & + & + & + & + & + & + & - & - \\
\hline TCRD-D2 & + & + & - & - & - & + & + & - & + & - & - & - \\
\hline IGH-A/IGH-B/IGH-C & - & - & - & - & - & + & - & - & + & +1 & + & + \\
\hline VK-A & - & - & - & - & - & + & + & - & - & - & + & - \\
\hline VK-B & - & - & - & - & - & - & + & + & - & - & - & - \\
\hline
\end{tabular}

Note. "+" - monoclonal rearrangement, "-" - polyclonal rearrangement, "+1" - initial clonal rearrangement is detected along with an additional rearrangement different from the one identified at the onset, $\mathrm{O}-$ onset, $\mathrm{R}$ - relapse.

be associated with our small sample size. Oligoclonal rearrangements (three or more clonal peaks) occurred both in B-ALL (IGH in 12\% (4 of 34) of patients, TCRD in $18 \%$ ( 6 of 34 ) of patients) and in T-ALL (TCRD in $32 \%$ (9 of 28) of patients).

In six patients, clonal rearrangements were investigated at the onset and relapse. A total of 17 clonal TCR and 5 clonal IG gene rearrangements were identified at the onset. Six clonal TCR and three clonal IG gene rearrangements different from those identified at the onset were detected at relapse (Table 6).

Two patients with B-cell ALL had a loss of one of the clonal rearrangements identified at the onset, with new rearrangements simultaneously emerging (patient 5 in Fig. 1 and patient 6 in Table 6). In one patient diagnosed with early precursor T-ALL, the clonal TCR $\gamma-, \beta-$, and 
Patient 5

Onset
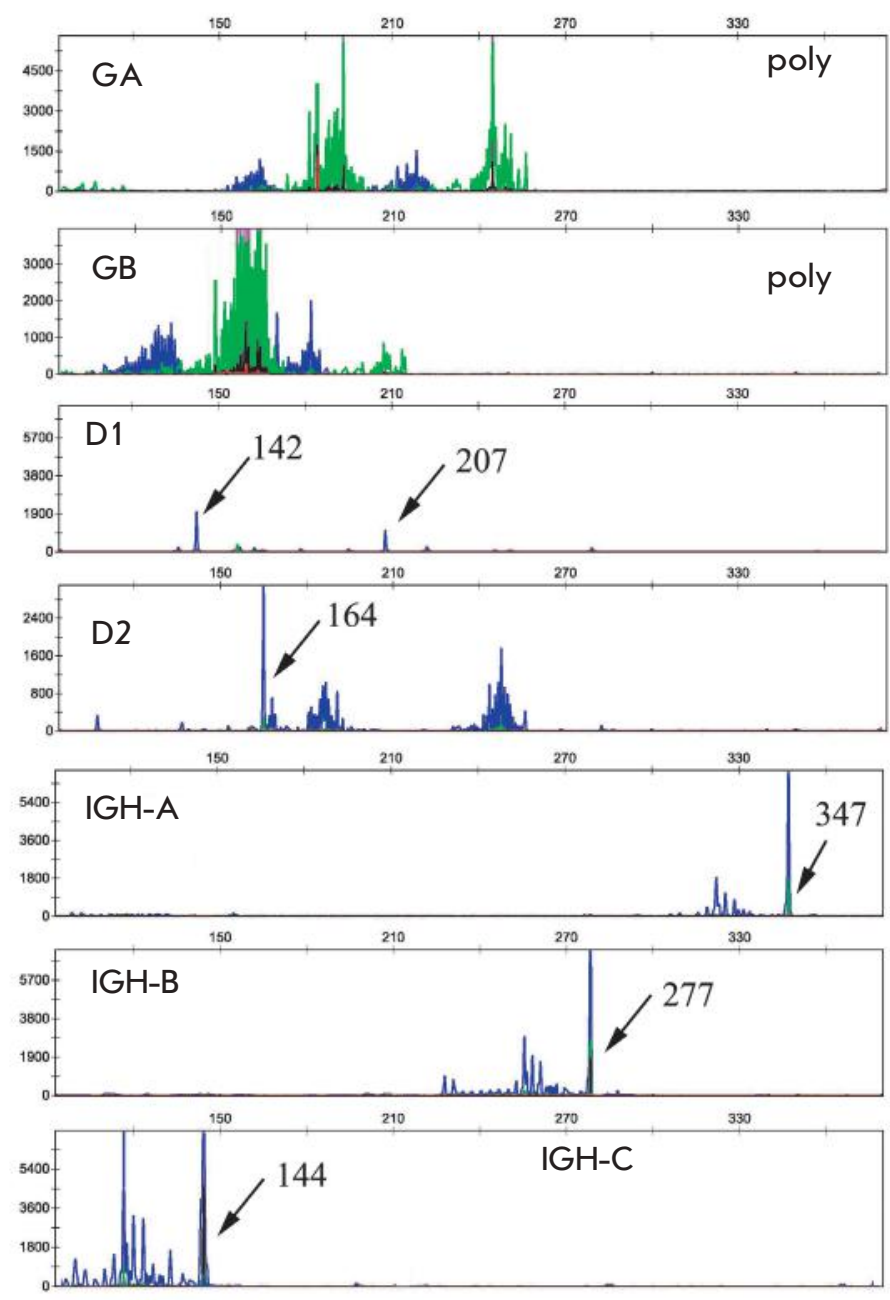

Relapse
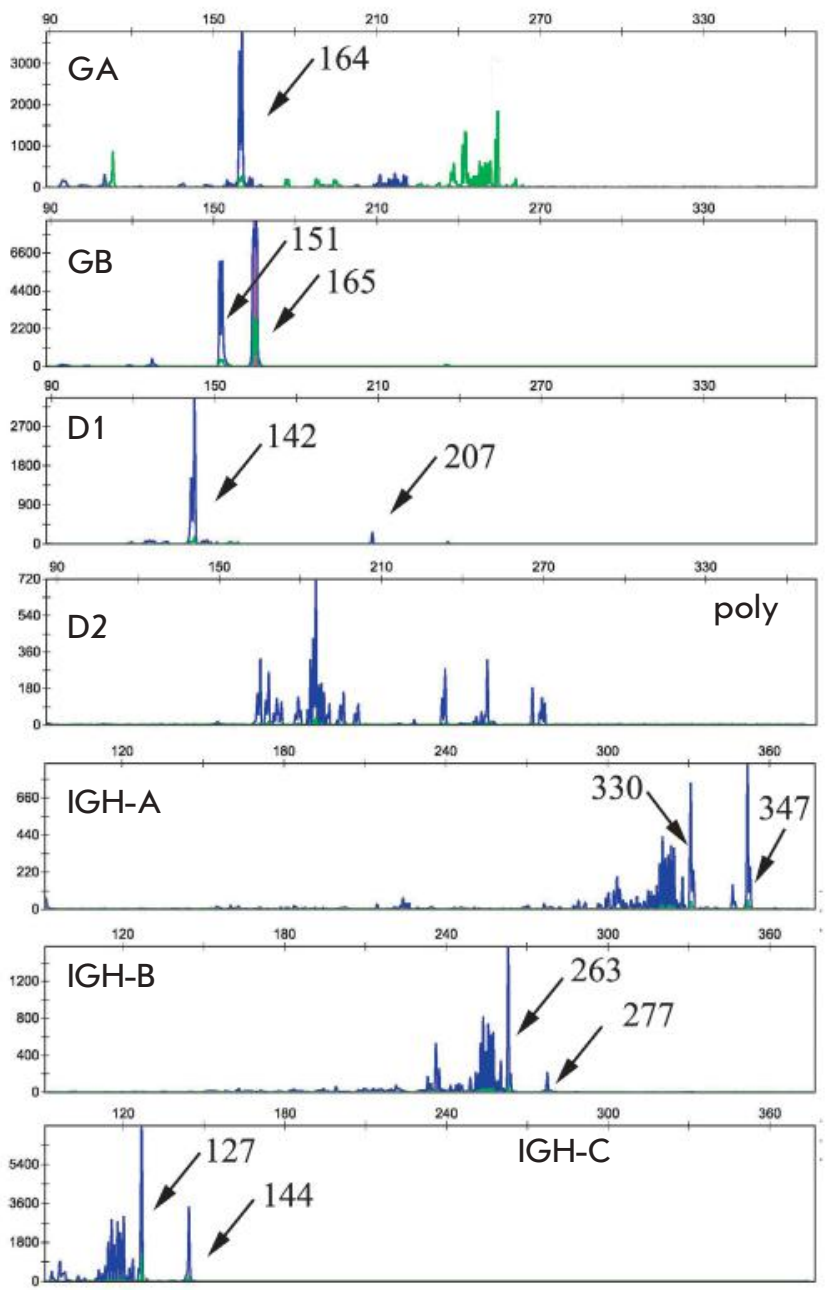

Fig. 1. Fragment analysis of $T C R, T C D$, and $I G H$ gene amplification products in patient 5 at the onset and relapse. Two 142 and 207 bp clonal products (indicated by arrows) of TCRD gene rearrangements and a 347 bp clonal product of IGH gene rearrangements were amplified at the disease onset. In this patient, the rearrangements remained at the relapse and new clonal products were also identified (TCRGA - $164 \mathrm{bp}$, TCRGB - 151 and $165 \mathrm{bp}$; IGHA - $330 \mathrm{bp}$, IGHB - $263 \mathrm{bp}$, IGHC - $127 \mathrm{bp})$.

$\delta$-chain gene rearrangements completely coincided at the onset and relapse (case 1). In one T-ALL patient, new rearrangements emerged, in addition to the clonal rearrangements identified at the onset (case 2). In one patient, only two of the seven rearrangements identified at the onset were preserved up to the relapse (Fig. 2 , patient 4 ). In one patient, only one clonal TCR $\delta$-chain gene rearrangement was detected at the B-ALL onset, which was preserved up to the relapse, but several new rearrangements emerged, including clonal IGH and IG light $x$-chain gene rearrangements.
We were able to demonstrate that at least one of the initially detected clonal products was preserved up to ALL relapse in all patients (Table 6). This confirms the data showing that at least one initial clonal product is preserved even in the case of late ALL relapse in children (more than 5 years after remission achievement) [27]. In our work, differences in clonal rearrangements at the onset and relapse were found in five out of six $(83 \%)$ patients. Even with this small sample size, we observed clonal evolution at relapse, which raises the issue of initial selection of the target for MRD quan- 
Patient 4

Onset

Relapse
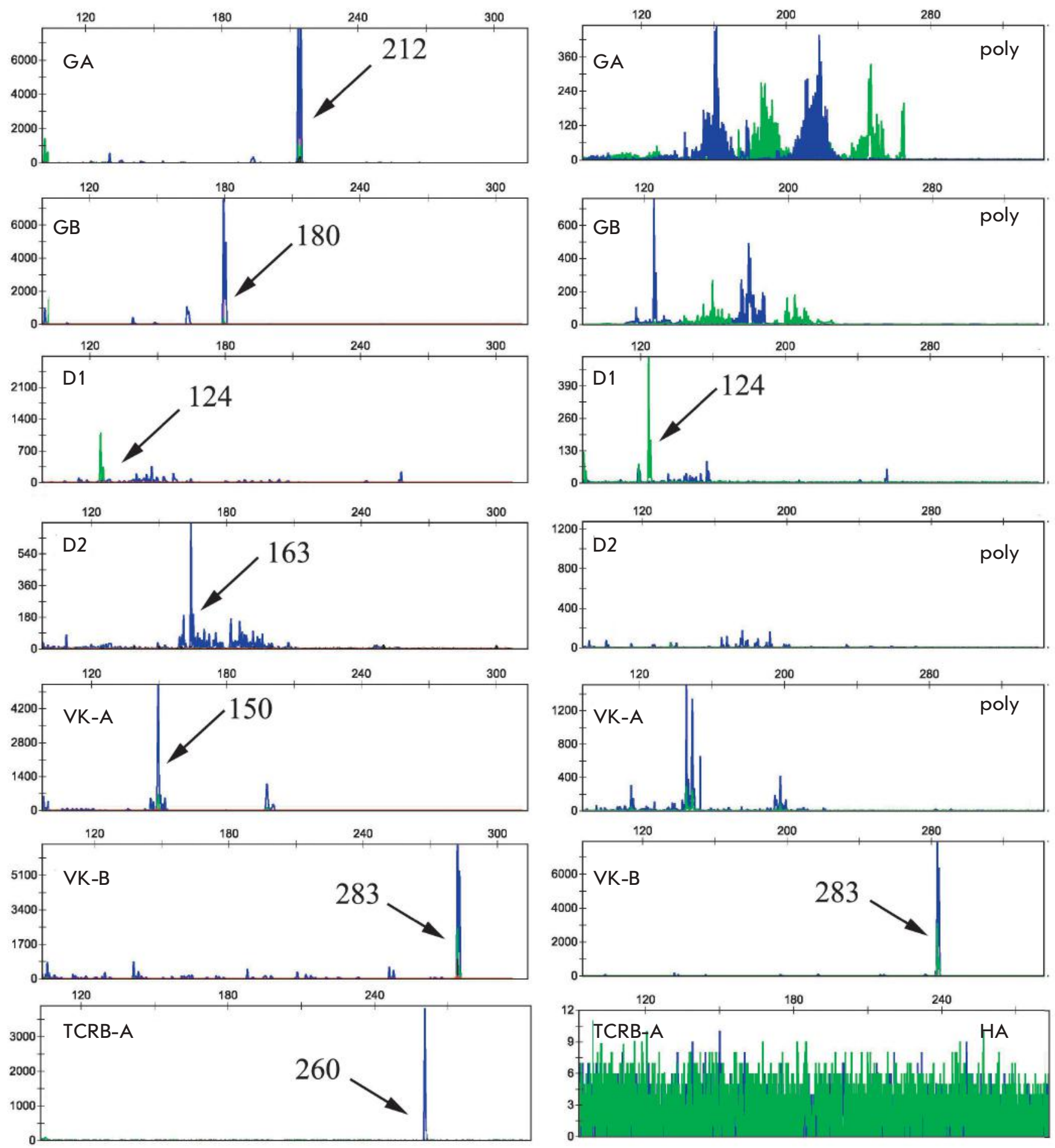

Fig. 2. Fragment analysis of TCRG, TCRD, IGK, and TCRB gene amplification products in patient 4 at the onset and relapse. Seven clonal rearrangements were identified at the diagnosis. Only two of them were preserved at the relapse ( TCRD - 124 bp; IGK - 283 bp). 
tification. At least two independent targets with high stability are conventionally used to minimize the risk of false positive results. However, in practice, a patient-specific primer with the desired specificity and sensitivity cannot be selected for every target. First of all, this applies to incomplete rearrangements or gene rearrangements lacking the D-segment, e.g. TCRG $(\mathrm{V} \gamma-\mathrm{J} \gamma)$. We found a loss of the patient-specific targets identified in three patients at the onset. To trace minor subclones at the onset and to evaluate their behavior in the presence of therapy, we decided to increase the initial sensitivity of the method. V-and J-family specific primers were used to re-examine the initial material for the presence of the clones that emerged at the relapse. The use of these primers increases the sensitivity of tumor cell detection from $10^{-1}$ to $10^{-2}-10^{-3}$. However, even with this sensitivity, subclones were not detected at the onset, which suggests a small size of the subclones and confirms the data of other studies. For example, in $77 \%$ (35 of 45) of childhood B-ALL cases, clones with new rearrangements at relapse were present only as small subclones at the onset [28]. The size of these resistant subclones ranged from $10^{-2}$ to $10^{-5}$ cells, and the lower the cell number was, the longer the time to relapse was [29].

Recently, acute lymphoblastic leukemias were shown to have a complex and genetically heterogeneous composition of tumor cells within one disease $[30,31]$. In most ALL cases, clonal evolution is based on the reactivation of one of the minor subclones, which is resistant to therapy [29, 32, 33]. Clonal diversity is the mechanism underlying tumor progression. Some clonal cells are likely to have properties that are different from those of other cells (genetic mutations, division rate, immunological maturity), making them resistant to chemotherapy. The causes behind late reactivation of the initial tumor clone remain unknown. Perhaps, the immune surveillance and the mechanisms

REFERENCES

1.Felix C. Acute lymphoblastic leukemia in infants. Washington: Education Program Book of hematology, American society of hematology, 2015. P. 285-302

2. Parovichnikova E.N., Troitskaya V.V., Sokolov A.N., Akhmerzaeva Z.Kh., Kuzmina L.A., Mendeleeva L.P., Klyasova G.A., Kravchenko S.K., Gribanova E.O., Bondarenko S.N., et al. // Oncohematology. 2014. № 3. P. 6-15.

3. Campana D., Pui C. // Blood. 1995. V. 85. № 6. P. 1416-1434.

4. Copelan E., McGuire E. // Blood. 1995. V. 85. № 5. P. 11511168.

5. Flohr T., Schrauder A., Cazzaniga G., Panzer-Grümayer R, van der Velden V, Fischer S, Stanulla M, Basso G, Niggli FK, Schäfer BW // Leukemia. 2008. V. 22. № 4. P. 771-782. 6. Brüggemann M., Raff T., Flohr T., Gökbuget N., Nakao M., Droese J., Lüschen S., Pott C., Ritgen M., Scheuring U., et al. // Blood. 2006. V. 107. № 3. P. 1116-1123. of antitumor immunity weaken, or new genetic mutations emerge in tumor cells that are then reactivated. The use of quantitative methods to evaluate MRD is an independent prognostic factor and a criterion for the stratification of patients into relapse-risk groups. The spectrum of clonal rearrangements can vary during the disease. This process can occur during early induction therapy, which leads to false negative results of MRD evaluation and prevents a stratification of patients into risk groups. Successful monitoring of the minimal residual disease can be ensured only through the selection of patient-specific primers for each clonal target identified at the onset.

\section{CONCLUSION}

Five out of six (83\%) patients studied had differences in clonal rearrangements at the onset and relapse, which indicates clonal instability in the presence of polychemotherapy. Tumor cells in ALL initially show a complex and genetically heterogeneous composition; while some clones disappear due to polychemotherapy, others that are unidentified because of the insufficient sensitivity of the method acquire the ability to activate. Clonal evolution is one of the mechanisms behind tumor progression and is a serious obstacle to the quantification of MRD by PCR. We have demonstrated that the absence of amplification with patient-specific primers selected for targets sequenced at the disease onset cannot fully guarantee an absence of residual disease because tumor clones were shown to be unstable in some cases of acute leukemia. Therefore, clonality should be re-examined in doubtful cases of suspected relapse and the absence of amplification with patient-specific primers. Investigation of clonal evolution mechanisms and the ability of chemotherapy to affect clonal evolution processes will contribute to the development of new prognostic factors and therapeutic approaches.

7. van Dongen J.J., van der Velden V.H., Brüggemann M., Orfao A. // Blood. 2015. V. 125. № 26. P. 3996-4009.

8. van der Velden V.H., Hochhaus A., Cazzaniga G., Szczepanski T., Gabert J., van Dongen J.J. // Leukemia. 2003. V. 17. P. $1013-1034$.

9. van Dongen J.J., Langerak A.W., Bruggemann M., Evans

P.A.S., Hummel M., Lavender F.L., Delabesse E., Davi F., Schuuring E., García-Sanz R. // Leukemia. 2003. V. 17. № 12. P. 2257-2317.

10. Pongerse-Willemse M.J., Seriu T., Stolz F., d'Aniello E., Gameiro P., Pisa P., Gonzalez M., Bartram C.R., Panzer-Grümayer E.R., Biondi A. // Leukemia. 1999. V. 13. P. 110-118. 11. Szczepański T., van der Velden V.H., Raff T., Jacobs D.C., van Wering E.R., Brüggemann M., Kneba M., van Dongen J.J. // Leukemia. 2003. V. 17. № 11. P. 2149-2156.

12. Szczepanski T., van der Velden V.H., Waanders E., Kuiper R.P., van Vlierberghe P., Gruhn B., Eckert C., Panzer-Grü- 


\section{RESEARCH ARTICLES}

mayer R., Basso G., Cavé H., et al. // ClinOncol. 2011. V. 29. № 12. P. $1643-1649$.

13. Beishuizen A., Verhoeven M.A., van Wering E.R., Hahlen K., Hooijkaas H., van Dongen J.J. // Blood. 1994. V. 83. № 8. P. 2238-2247.

14. Aihong Li Jianbiao Z., David Z., Montse R., Virginia D., Cheryl L., Lewis B.S., Stephen E. S., John G.G. // Blood. 2003. V. 102. № 13. P. 4520-4526.

15. Szczepański T., Willemse M.J., Brinkhof B., van Wering E.R., van der Burg M., van Dongen J.J. // Blood. 2002. V. 99. № 7. P. 2315-2323.

16. van der Velden V.H., Szczepanski T., Wijkhuijs J.M., Wijkhuijs J.M., Hart P.G., Hoogeveen P.G., Hop W.C.J, van Wering E.R., van Dongen J.J.M. // Leukemia. 2003. V. 17. № 9. P. 1834-1844.

17. Beishuizen A., Hahlen K., Hagemeijer A., Verhoeven M.A., Hooijkaas H., Adriaansen H.J., Wolvers-Tettero I.L., van Wering E.R, van Dongen J.J. // Leukemia. 1991. V. 5. № 8. P. 657-667.

18. Beishuizen A., de Bruijn M.A., Pongers-Willemse M.J., Verhoeven M.-A.J., van Wering E.R., Hählen K., Breit T.M., de Bruin-Versteeg S., Hooijkaas H., van Dongen J.J.M. // Leukemia. 1997. V. 11. № 12. P. 2200-2207.

19. Bruggemann M., van der Velden V.H., Raff T., Droese J., Ritgen M., Pott C., Wijkhuijs A.J., Gökbuget N., Hoelzer D., van Wering E.R. // Leukemia. 2004. V. 18. № 4. P. 709-719.

20. Breit T.M., WolVers-Tettero I.L., Beishuizen A., Verhoeven M.A., van Wering E.R., van Dongen J.J. // Blood. 1993. V. 82. № 10. P. 3063-3074.

21. Szczepański T., Langerak A.W., Willemse M.J., Wolvers-Tettero I.L., van Wering E.R., van Dongen J.J. // Leukemia. 2000. V. 14. № 7. P. 1208-1214.

22. van der Velden V.H., Wijkhuijs J.M., Jacobs D.C., van Wering E.R., van Dongen J.J. // Leukemia. 2002. V. 16. № 7. P. $1372-1380$.

23. Willemse M.J., Seriu T., Hettinger K., d'Aniello E., Hop W.C., Panzer-Grümayer E.R., Biondi A., Schrappe M.,
Kamps W.A., Masera G., et al. // Blood. 2002. V. 99. № 12. P. 4386-4393.

24. Germano G., del Giudice L., Palatron S., Giarin E., Cazzaniga G., Biondi A., Basso G.. // Leukemia. 2003. V. 17. № 8. P. 1573-1582.

25. Sidorova Yu.V., Sorokina T.V., Biderman B.V., Nikulina E.E., Kisilichina D.G., Naumova E.V., Pochtar' M.E, Lugovskaya S.A., Ivanova V.L., Kovaleva L.G., et al. // Klin Lab Diagn. 2011. № 12. P. 22-35.

26. Dongen J.J., Langerak A.W., Bruggemann M., Evans P.A., Hummel M., Lavender F.L., Delabesse E., Davi F., Schuuring E., García-Sanz R., et al. // Leukemia. 2003. V. 17. № 12. P. 2257-2317.

27. Lo Nigro L., Cazzaniga G., Di Cataldo A., Pannunzio A, D’Aniello E., Masera G. Schiliró G., Biondi A. // Leukemia. 1999. V. 13. P. $190-195$.

28. Eckert C., Flohr T., Koehler R., Hagedorn N., Moericke A., Stanulla M., Kirschner-Schwabe R., Cario G., Stackelberg A., Bartram C.R., et al. // Leukemia. 2011. V. 25. № 8. P. 1305-1313.

29. Choi S., Henderson M.J., Kwan E., Beesley A.H., Sutton R., Bahar A.Y., Giles J., Venn N.C., Pozza L.D., Baker D.L., et al. // Blood. 2007. V. 110. № 2. P. 632-639.

30. Mullighan C.G., Zhang J., Kasper L.H., Lerach S., Payne-Turner D., Phillips L.A., Heatley S.L., Holmfeldt L., Collins-Underwood J.R., Ma J., et al. // Nature. 2011. V. 471. № 7337. P. 235-239.

31. Gawad C., Pepin F., Carlton V.E., Klinger M., Logan A.C., Miklos D.B., Faham M., Dahl G., Lacayo N. // Blood. 2012. V. 120. № 22. P. 4407-4417.

32. Li A, Zhou J., Zuckerman D., Rue M., Dalton V., Lyons C., Silverman L.B., Sallan S.E., Gribben J.G. // Blood. 2003. V. 102. № 13. P. 4520-4526.

33. de Haas V., Verhagen O.J., von dem Borne A.E., Kroes W., van den Berg H., van der Schoot C.E. // Leukemia. 2001. V. 15. № 1. P. 134-140. 